\title{
Podkarpatská Rus v československé ústavě a na Ústavním soudu
}

\author{
David Hubený
}

Oddělení fondů státní správy z let 1918-1945, Národní archiv

Kontaktni e-mail: david.hubeny@nacr.cz

\begin{abstract}
Subcarpathian Ruthenia in the Czechoslovak Constitution and before Constitutional Court
\end{abstract}

\begin{abstract}
:
The article deals with the Subcarpathian Ruthenia in the Czechoslovak Constitution of 1920 and its rights, as well as with some aspects of the preparation of the Constitution. The attention is also paid to the tasks of the Constitutional Court and the search for adequate representatives of the Subcarpathian Ruthenia therein.
\end{abstract}

Keywords: Constitution, Constitutional Court; Subcarpathian Ruthenia, Czechoslovakia

Klíčová slova: Ústava, Ústavní soud, Podkarpatská Rus, Československo

DOI: $10.14712 / 2464689 X .2021 .19$

Při vyhlášení Československého státu 28. října 1918 nikdo z domácích politických představitelů neměl ani ponětí, že budoucí součástí státu se stane území později nazvané Podkarpatská Rus. Příslušná jednání mezi exilovými reprezentanty Rusínů a československého odboje tehdy sotva započala. ${ }^{1} \mathrm{~S}$ přičleněním Podkarpatské Rusi nepočítala ani prozatímní ústava (č. 37/1918 Sb. z. a n.) ze dne 13. listopadu 1918 a pražská vláda se o této možnosti patrně dozvěděla až na přelomu listopadu a prosince, přičemž počátkem prosince 1918 na jednání vlády zaznělo: „Rusové [tj. Rusíni] žádají za připojení k nám, jestliže dáme jim: autonomii ve školství, soudnictví, církvi a administraci; na slovenské univerzitě stolici ruské řeči, popřípadě ruskou univerzitu.“ Vláda reagovala prostě: „Usnáší se, aby vypracovali Slováci i Rusové dotyčný návrh.“2 Zatímco otázka realizace autonomie

KROFTA, K. Podkarpatská Rus a Československo. II. vydání. Praha: Česká expedice, 1995, s. 5.

Národní archiv, fond Předsednictvo ministerské rady (dále jen NA, f. PMR), kart. 4029, I. vláda, 14. zasedání z 3. prosince 1918, fol. 189. 
se během první republiky 33 stala permanentně odkládaným krokem, resp. postupovalo se při její implementaci jen drobnými krůčky, aby došla svého problematického naplnění během druhé republiky, ${ }^{4}$ kdy se Podkarpatská Rus, resp. Karpatská Ukrajina, stala jen nástrojem nacistického Německa k destabilizaci pomnichovské republiky, tak v oblasti ústavního zákonodárství československá ústava z roku 1920 (č. 121/1920 Sb. z. a n.) již s Podkarpatskou Rusí počítala a na rozdíl od autonomie měly další odkazy vztahující se k Podkarpatské Rusi praktické důsledky v podobě jejího zastoupení v různých soudních a úředních orgánech.

Příspěvek nejprve seznamuje se stručnými zmínkami ústavy o Podkarpatské Rusi, přičemž zohledňuje i jazykový zákon, a poté rozebírá otázku personálního zastoupení Podkarpatské Rusi na Ústavním soudu během jeho obou funkčních období. Všímá si proměn preferencí jednotlivých kandidátů a vůbec obtíží s vyhledáním reprezentativních osob v politickém a odborném smyslu. ${ }^{5}$ Následně se zabývá dvěma podněty, které Ústavní soud řešil ve vztahu k Podkarpatské Rusi a jeho svérázným rozhodnutím z období nacistické okupace.

\section{Ústava}

Poté, co již bylo jasné, že se Podkarpatská Rus stala pevnou součástí státu, mohla se tato skutečnost promítnout i do přípravy a definitivní podoby základního zákona státu, čemuž předcházely různé - nejen legislativní a politické - diskuze, ale i tiskové zprávy a kampaně připomínající např. skutečnost, že ve vztahu k Podkarpatské Rusi nebude moci zákonodárné shromáždění republiky postupovat jen dle svého uvážení, ale bude muset brát v potaz mezinárodní závazky a členství ve Společnosti národů, z čehož vyplývalo určité omezení svrchovanosti Národního shromáždění. ${ }^{6}$

O svá práva se před přijetím ústavy hlásili též představitelé Podkarpatské Rusi, kteří požadovali zvláštní ústavu Podkarpatské Rusi, včetně všeobecného volebního práva (i pro ženy), rozvoj rusínského jazyka a všech druhů školství, omezení osobních úkonů ve prospěch kněží, ale zároveň co nejširší náboženskou svobodu, zrušení dětské práce a zavedení osmihodinové pracovní doby, vznik autonomní zemské banky a pochopitelně pozemkovou reformu. Menšiny měly být chráněny podle vzoru saint-germainské menšinové smlouvy. ${ }^{7}$

3 K první republice a Podkarpatské Rusi např. RYCHLÍK, J. - RYCHLÍKOVÁ, M. Hospodářský, sociální, kulturní a politický vývoj Podkarpatské Rusi 1919-1939. Praha: Národohospodářský ústav Josefa Hlávky, 2013, a RYCHLÍK, J. - RYCHLÍKOVÁ, M. Podkarpatská Rus v déjinách Československa 1918-1946. Praha: Vyšehrad, 2016.

$4 \quad$ K druhé republice a Podkarpatské Rusi např. HOLUB, O. Boje československé armády a jednotek Stráže obrany státu na Podkarpatské Rusi (Karpatské Ukrajině) v březnu 1939. Odboj a revoluce. Zprávy, 1969, roč. VII., č. 5, s. 5-74; JEDLIČKA, J. Podkarpatská Rus/Karpatská Ukrajina v březnu 1939. In: DEJMEK, J. - HANZAL, J. (eds.). České země a Československo v Evropě XIX. a XX. století. Sborník prací k 65. narozeninám prof. Dr. Roberta Kvačka. Praha: Historický ústav, 1997, s. 409-424; HUBENÝ, D. Podkarpatská Rus na jednáních vlád Jana Syrového (23. září - 1. prosince 1938). Paginae historiae, 2013, roč. 21, č. 1, s. 191-232.

5 Ústavní soudce z Podkarpatské Rusi kupodivu zcela opomíjí jinak důkladná práce Ivana Popa - POP, I. Podkarpatská Rus. Osobnosti jeji historie, vědy a kultury. Praha: Libri, 2008.

6 Např. KUKLÍK, J. Př́běh československé ústavy 1920. Díl I. Př́prava a prijietí ústavní listiny. Praha: Karolinum, 2020, s. 116-117.

7 Tamtéž, s. 162. 
Vláda v návaznosti na vrcholící přípravy $\mathrm{k}$ přijetí definitivní podoby ústavy a s ohledem na publikované požadavky rusínských představitelů považovala za vhodné projednat tyto otázky formou vyslání svého zástupce na Podkarpatskou Rus, ale s přihlédnutím na všestranně rozháranou a neklidnou situaci na Podkarpatské Rusi se rozhodla ponechat fungující vojenskou správu a jí podřízenou Civilní správu Podkarpatské Rusi a v případě nutnosti odložit konání voleb na vhodnější dobu. Pro zajištění flexibility se vláda rozhodla pro rámcové řešení práv Podkarpatské Rusi, které by byly posléze specifikovány podrobnějšími konkrétními předpisy. ${ }^{8}$

S výše naznačenými omezeními tedy československá ústava (č. 121/1920 Sb. z. a n.) př́mo operovala a pojímala československý národ jako lid českých zemí, Slovenska a Podkarpatské Rusi. ${ }^{9}$ Nejrozsáhleji se Podkarpatské Rusi týkal paragraf 3, který vypočítával hlavní náležitosti týkající se autonomní Podkarpatské Rusi. Tento paragraf přímo zmiňoval smlouvu z 10. záŕí 1919, což bylo a je v právní praxi něco mimořádného. ${ }^{10}$ Paragraf 3 též připomínal požadavek co nejširší možné autonomie slučitelné s celistvostí státu. Dále garantoval vznik vlastního sněmu, jenž si vyvolí své předsednictvo a rovněž zaručoval přiměřené zastoupení v Národním shromáždění i přednostní dosazování místních rodáků do orgánů státní správy, jestliže to bude možné. Generální zpravodaj Václav Bouček v této souvislosti zákonodárcům sdělil, že řešení postavení Podkarpatské Rusi není problematické, nebot' ústava zde přejímala již dříve přijatý závazek ve vztahu k autonomii Podkarpatské Rusi. ${ }^{11}$

Oproti menšinové smlouvě z 10. záŕí 1919 byl prezident republiky vybaven absolutním právem veta vůči zákonům podkarpatoruského sněmu. Otevřené rovněž zůstalo, co dalšího připadne do kompetence předpokládaného sněmu. Ústava oproti menšinové smlouvě rovněž nově určila, že guvernér je odpovědný nejen sněmu, ale i vládě republiky, která guvernéra jmenovala. Ani to československá strana nepovažovala za porušení menšinové smlouvy. ${ }^{12}$

Teprve po podpisu prezidenta republiky mohl guvernér zákon sněmu Podkarpatské Rusi spolupodepsat a vyhlásit ve zvláštní sbírce. Způsob publikace zákonů sněmu Podkarpatské Rusi vyvolal mezi ústavními právníky nejasnosti, nebot' se ustanovení ústavy mohla vykládat tak, že se zákony vyhlašují ve zvláštní sbírce zákonů Podkarpatské Rusi a do celostátní sbírky vůbec nepatří, ale i tak, že se otiskují jen v celostátní sbírce zákonů, popřípadě v obou sbírkách, jak celostátní, tak podkarpatoruské. Otázkou pak bylo, který výklad a která sbírka (včetně odlišného data vydání) by byla určující. Jelikož však sněm během první republiky neexistoval, jednalo se o čistě akademickou debatu, kterou by v př́ípadě aktuálnosti rozřešil až Ústavní soud. ${ }^{13}$

\footnotetext{
Tamtéž, s. 178-179.

BROKLOVÁ, E. Sté výročí vzniku první československé ústavy. Právník, 2020, roč. 159, č. 2, s. 93.

PETRÁŠ, R. Menšiny v meziválečném Československu. Právni postavení menšin v první Československé republice a jejich mezinárodněprávní ochrana. Praha: Karolinum, 2009, s. 289.

11 K vystoupení generálního zpravodaje ve vztahu k Podkarpatské Rusi viz KUKLÍK, op. cit., s. $203-205$.

12 PEŠKA, Z. Národní menšiny a Československo. Bratislava: Právnická fakulta university Komenského, 1932, s. 209.

13 WEYR, F. Soustava československého státního práva. 2. vydání. Praha: Fr. Borový, 1924, s. 97, včetně pozn. 1 (s. 97) a 3 (s. 97-98).
} 
Guvernér Podkarpatské Rusi byl jmenován prezidentem na návrh vlády (§ 3). Guvernéra a podkarpatoruského sněmu se částečně týkal pozdější zákon na ochranu republiky, resp. o státním soudě (č. 50 a č. 51/1923 Sb. z. a n.). Před Státní soud se totiž měl dostat každý, kdo vyhrožoval guvernéru Podkarpatské Rusi, prezidentu republiky nebo zákonodárným sborům použitím ,násilí, aby působil v určitém směru na výkon pravomoci [...] neb aby jim v takovém výkonu bránil nebo jej mařil, kdo proti nim užije násilí za výkon jich pravomoci“". Stejně trestné bylo osobovat si pravomoci prezidenta republiky, guvernéra Podkarpatské Rusi nebo zákonodárného sboru. Za tyto činy mohl být udělen trest 1-5 let, popř. při prritěžujících okolnostech 5-10 let těžkého žaláře (§ 10 zák. č. 50/1923 Sb. z. a n.).

Ústava také konstatovala, že státní občanství bude jednotné pro celou republiku ( $\S$ 4), tedy zamezovala vzniku specifického podkarpatoruského státního občanství, což se záhy projevilo jako moudré v souvislosti s tím, jak se na Podkarpatské Rusi začaly objevovat různé emigrantské proudy, které byly původně vítané jako zdroj vhodných kádrů pro naplnění státní správy jazykově vybavenými osobami, které však neváhaly využívat a zneužívat své pozice ve státní správě, takže viceguvernér Podkarpatské Rusi byl nucen proti přijímání těchto sil energicky zakročit. ${ }^{14}$

Hlava šestá ústavy volně opakovala zásady smlouvy z 10. záríi 1919 a nově v § 134 jednoznačně konstatovala: „Jakýkoliv způsob násilného odnárodňování je nedovolený.“

Národní shromáždění sice vydávalo zákony pro celé území ČSR, ale v případě existence sněmu Podkarpatské Rusi by se jeho suverenita zúžila, nebot' by „,preneslo část své pravomoci pro území Podkarpatské Rusi na sněm pro ně zřízený, který tudíž svou pravomoc odvozuje státoprávně od Nár. shromáždění. Pokud Nár. shrom. změnou ústavy neupraví pravomoc jeho jinak, nemůže zasahovati do oboru jeho působnosti. “Sněm by rozhodoval o otázkách školních, náboženských atp., jak je jmenovala menšinová smlouva. ${ }^{15}$ Právní teoretici se ovšem domnívali, že k přesnějšímu vymezení úkolů sněmu Podkarpatské Rusi, až se sejde, bude přeci jen třeba podrobnějšího a přesnějšího zákona, než jak práva podkarpatoruského sněmu vyjadřovala ústava, resp. mezinárodní smlouva. Teoreticky mohlo Národní shromáždění při porušení mezinárodního práva zrušit ústavním zákonem podkarpatoruskou autonomii. ${ }^{16}$

Ústava také určovala, že vnitřní hranice Podkarpatské Rusi mezi ní a Slovenskem bude ještě určena zvláštním zákonem. Otázka hranic mezi oběma zeměmi republiky se stala ožehavou politickou otázkou mezi politickými reprezentacemi obou východních částí republiky, ${ }^{17}$ ale pro slovenské zástupce to byla marginální otázka, nebot’ je přirozeně mnohem více zajímal vztah k českým zemím. ${ }^{18}$

14 Podrobněji viz HUBENÝ, D. Možnosti a problémy při využití emigrantů při budování československé správy na Podkarpatské Rusi. Русская и украинская эмиграция в Подкарпатской Руси и Чехословацкое государство: Эмиграция из царской России и создание чехословацкой системы управления в Подкарпатской Руси. In: Как зарождалась Русская Прага. Международный сборник статей материалов международного круглого стола в Праге 26. 06. 2017. Москва: РГГУ, 2017, s. 78-92.

17 Podrobně viz ŠVORC, P. Krajinská hranice medzi Slovenskom a Podkarpatskou Rusou v medzivojnovom obdobi (1919-1939). Prešov: Universum, 2003.

18 ŠVORC, P. Namiesto úvodu: Slováci a Rusíni pred vznikom Československa. In: ŠVORC, P. DERFIŇÁK, P. (eds.). Podkarpatská Rus a východné Slovensko v súradniciach času (1918-1939). Čriepky z histórie. Prešov: Universum, 2017, s. 22. 
Ústava nevyužila možnost menšinové smlouvy, aby rusínští poslanci byli vyloučeni z hlasování o věcech Podkarpatské Rusi. ${ }^{19}$ Původně se sice s touto možností operovalo, ale Karel Kramář prosadil pro podkarpatoruské členy Národního shromáždění výhodnější řešení. ${ }^{20}$ Bylo to prozíravé řešení - poslanci a senátoři zvolení za Podkarpatskou Rus mohli i v Národním shromáždění hlasovat a hovořit o otázkách týkajících se Podkarpatské Rusi, dokud nebude zvolen tamější sněm a Praze tak nemohlo být vytýkáno, že Rusíni nemají žádných volených reprezentantů v nejvyšší politice, ba že v ní nejsou ani slyšet, ${ }^{21}$ i když tato úvaha byla asi vedlejší a rusínští zákonodárci v Praze by nepochybně měli nadále takovou možnost, i kdyby byl sněm zvolen. Znění norem ostatně zřejmě předpokládalo, že sněm Podkarpatské Rusi bude jednokomorový. ${ }^{22}$ Ovšem samotná existence sněmu Podkarpatské Rusi zavdávala příčinu k teoretickým právním úvahám, že Československo není jednotným státem, nýbrž státem složeným s dvěma právními řády ${ }^{23}$ (československým a podkarpatoruským; otázka přežívání uherského práva na Slovensku a vlastně i na Podkarpatské Rusi může být $\mathrm{v}$ této souvislosti pominuta). Podle jednacích řádů obou komor Národního shromáždění mohli poslanci a senátoři za Podkarpatskou Rus na jednáních v Národním shromáždění a Stálém výboru užívat bud' jazyk státní, nebo jazyk sněmu Podkarpatské Rusi, resp. patřili-li k německé nebo mad'arské menšině, tak jazyk své menšiny. V těchto jazycích mohli podávat též interpelace, dotazy a návrhy, pokud tak neučinili sami a nepřipojili československý překlad, který mohlo nechat vedení sněmovny překontrolovat a opravit tlumočníkem. Ve své mateřštině rovněž mohli skládat své poslanecké a senátorské sliby. V oficiálních zápisech se pak objevovaly překlady z menšinových jazyků do jazyka československého. V př́lohách čtenář nalezl promluvy a záznamy v původním znění. Odpovědi na interpelace se tiskly jak v československé variantě, tak v tom jazyku, v jakém byl dotaz podán. Rovněž prezidentské proslovy se překládaly do menšinových jazyků. ${ }^{24}$ Pozdější zákon č. 205/1925 Sb. z. a n., resp. jeho § 53, chránil národnosti proti mandátovému zkrácení ve volbách do Národního shromáždění. ${ }^{25}$

$\mathrm{K}$ ústavě se vztahovala též Zpráva ústavního výboru, kde se mimo jiné uvádělo, že rusínský národ „se připojil a vědomě spolu s námi vytvořil stát jediný, tedy nikoli federativní nebo spolkový.“ $26 \mathrm{~K}$ tomu důvodová zpráva rríkala: ,úprava autonomie Podkarpatské Rusi, uložená nám jako závazek mezinárodní, s hlediska vnitrostátního jeví se jako akt svrchovanosti našeho ${ }^{27}$ státu, že právně jest řečená autonomie odvozena ze státní moci naší

\footnotetext{
19 KřEPINSKÝ, J. Autonomie Podkarpatské Rusi. In: Osm přednášek o Podkarpatské Rusi. Praha: Čes. učení politické, 1925, s. 21.

20 KUKLÍK, op. cit., s. 183-184.

21 MOSNÝ, P. Podkarpatská Rus. Nerealizovaná autonómia. Bratislava: Slovak Academic Press, 2001, s. 83; HOUSER, Jaroslav. Zakarpatská Ukrajina a buržoasní předmnichovská republika. Právník. Časopis pro právni theorii a právni praksi, roč. 91, 1952, s. 572.

22 Ǩ̌EPINSKÝ, op. cit., s. 21.

23 WEYR, op. cit., s. 112-114 a př́islušné poznámky pod čarou.

24 Viz $§ 49$ zákonů č. 325/1920 Sb. z. a n., o jednacím řádu poslanecké sněmovny Národního shromáždění, a č. 326/1920 Sb. z. a n., o jednacím řádu senátu Národního shromáždění.

25 SOBOTA, E. Národnostní právo československé. Brno: Barvič \& Novotný, 1927, s. 21.

26 Tisk Národního shromáždění č. 2421/1920, Zpráva ústavního výboru, s. 3.

27 V originále psáno proloženě, zde nahrazeno podtržením.
} 
republiky. “28 Je proto logické, že o oddělení Podkarpatské Rusi by rozhodovalo podle $\S 3$ ústavy jen Národní shromáždění ústavním zákonem.

Zařazení otázky autonomie Podkarpatské Rusi do základního zákona státu také představovalo demonstraci ochoty, vůle a odhodlání autonomii provést, resp. doklad toho, že Československo nebere své závazky na lehkou váhu. Pravdou ovšem je, že - zcela pragmaticky - ústava nehovoří o tom, kdy bude kýženého ideálního stavu, tj. autonomie, dosaženo. ${ }^{29}$ Řešení autonomie Podkarpatské Rusi v ústavě se líbila také některým slovenským politikům, zejména ze Slovenské národní strany, kteří v ní viděli vhodný vzor pro autonomii Slovenska. ${ }^{30}$

S ohledem na poválečný chaos a nedostatek bylo logické, že stát byl ústavou budován jako centralistický, tedy aby lépe dostál dobovým výzvám a snáze disponoval omezenými zdroji. Jedinou výjimku tedy představovala v budoucnu autonomní Podkarpatská Rus. ${ }^{31}$ Ostatně otálení či rozpaky s udělením brzké autonomie se objevily již v rámci přípravy ústavy, kdy si Masaryk 9. února 1920 posteskl nad budoucími problémy s menšinami a otevřeně doznal, že „slabé Rusínsko by sotva odolalo lákání Mad'arů i Polákư“, přičemž naznačil i možnou ztrátu podpory velmocí existenci Československa, pokud by republika vůči svým menšinám postupovala tvrdě. ${ }^{32}$ Mnohé špionážní a jiné aféry, jakož i problém s hledáním loajálních a odborně zdatných kádrů, dávalo těmto obavám za pravdu. Byl nezbytně potřebný čas, aby dorostla spolehlivá rusínská inteligence.

\section{Jazykový zákon}

Se základními zákony státu souvisel též jazykový zákon z 29. února 1920 č. 122. Podle něho se mimo Podkarpatskou Rus stal místní jazyk jazykem menšinovým, ale uvnitř Podkarpatské Rusi měl jazyková pravidla určit předpokládaný sněm „způsobem slučitelným s jednotností státu československého“; do té doby platila ustanovení jazykového zákona (§ 6), která Rusínům zajišt’ovala, že v celé Podkarpatské Rusi (i v okresech, kde Rusíni tvořili méně než 20 procent) mohou svůj jazyk používat při jednání s úřady. Státní budovy, úřrady a vyhlášky měly být rovněž dvojjazyčné, tj. v rusínštině (popř. ruštině nebo maloruštině, tj. ukrajinštině) a oficiálním státním jazyku. Na území Podkarpatské Rusi mohli tento jazyk používat i příslušníci ostatních menšin, včetně příslušníků československého jazyka, jenž byl na Podkarpatské Rusi rovnoprávný s rusínským jazykem. ${ }^{33}$ Prvorepublikové právo a právní normy se však nedokázaly shodnout na jednotném označení jazyka, který bude na Podkarpatské Rusi rovnoprávný s československým jazykem, ${ }^{34}$ což souviselo s tím, že místní hovořili množstvím dialektů a že se nikdy nesešel sněm, který by otázku závazně vyřešil. Díky tomu se ovšem nemusela řešit otázka práv jazyka Podkarpatské Rusi a jazyka československého na Podkarpatské Rusi, která by se v opačném případě jistě naskytla, byt'

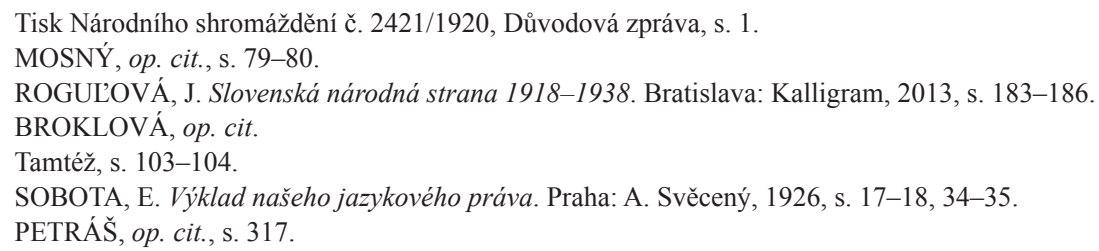


se nabízelo řešení, že státní úřady budou dvojjazyčné, kdežto ostatní záležitosti se budou vyřizovat jen v jazyku Podkarpatské Rusi. ${ }^{35}$

Ještě před přijetím jazykového zákona bylo na podzim 1919 Civilní správou Podkarpatské Rusi nařízeno, aby pokud obchody, továrny, banky atd. „mají nápisy, firmy, nebo označení na venek provedeny pouze v jazyku mad'arském, tato označení, firmy nebo nápisy provedly zároveň v jazyce ruském, českém nebo slovenském.“ Pochopitelně „nápisy slovanské“ musely být stejně veliké jako nápisy mad'arské. Většina obchodníků volila ruský text, což vyvolalo nelibost některých zástupců jiných slovanských jazykových směrů. ${ }^{36}$

Rozhodně je však nutno odmítnout názor, že jazykovou otázku Československo používalo jako metodu „rozděl a panuj“, tedy aby se místní obyvatelstvo rozeštvalo a lépe ovládlo. Stejným nesmyslem je i to, že by Praha prováděla „politiku násilné čechizace ukrajinského obyvatelstva““, jak po druhé světové válce šiřila sovětská propaganda. ${ }^{37}$ Naopak, okázalé závody židovských obchodníků v zavádění českých nápisů dělaly úředníkům starost, aby v tom nebyl spatřován úř̌ední úmysl. ${ }^{38}$ Demokratický stát nechtěl nikomu nic vnucovat, a tímto svým postojem si dokonce i škodil. Jazyk si muselo určit samo obyvatelstvo Podkarpatské Rusi, resp. jeho sněm.

Ochrana jazyka a menšin se projevila i v zákoně na ochranu republiky (č. 50/1923 Sb. z. a n.), jehož $\S 14$ o rušení obecného míru zahrnul do těchto aktivit veřejné popuzování „,k násilnostem nebo jiným nepřátelským činům proti jednotlivým skupinám obyvatelů pro jejich národnost, jazyk, rasu nebo náboženství, nebo proto, že jsou bez vyznání". Takovou činnost ocenil zákon vězněním v rozsahu 1-12 měsíců. Popuzování k zášti proti jednotlivým skupinám obyvatel se pak trestalo vězněním od 14 dnů do 6 měsíců a vůči konkrétnímu jedinci vězením od 8 dnů do 3 měsíců. Stejně se trestalo hanobení republiky, národa nebo národnostní menšiny.

Hodnota papírových bankovek navíc měla být podle zákonů č. 347/1920 (§ 18) a č. 102/1925 (článek VI.) Sb. z. a n. uvedena též v ruském (maloruském) jazyce (spolu s němčinou, mad'arštinou, polštinou a slovenštinou).

\section{Ústavní soud a zástupci Podkarpatské Rusi v prvním funkěním období}

Již článek druhý ústavy se zmiňoval v souvislosti s existencí Ústavního soudu a jeho pravomocech o tom, že tento soud přezkoumává ústavnost zákonů přijatých Národním shromážděním a zákonů vzniklých na „sněmu Podkarpatské Rusi“. Sněm Podkarpatské Rusi mohl spolu s dalšími orgány iniciovat jednání Ústavního soudu ohledně ústavnosti zákonů a spolu s komorami Národního shromáždění se měl podílet na volbě části ústavních soudců. ${ }^{39}$ Ústavní soud mohl svá jednání přizpůsobit rusínštině. ${ }^{40}$

Hledání vhodných kandidátů na pozici podkarpatoruského ústavního soudce může osvětlit, jak veliké personální problémy vládly na Podkarpatské Rusi a jak obtížně se do praxe přenášela litera, ale i duch ústavy a mezinárodních závazků.

\footnotetext{
35 WEYR, op. cit., s. 416-417.

36 NA, f. Ministerstvo vnitra I. - prezídium (dále jen PMV), sign. 225-190-4, fol. 45-45v.

37 JEVSEJEV, I. F. Z dějin Zakarpatské Ukrajiny. Praha: SNPL, 1956, s. 32 a 34.

38 NA, f. PMV, sign. 225-194-6, fol. 35-36.

39 LANGÁŠEK, T. Ústavni soud Československé republiky a jeho osudy v letech 1920-1948. Plzeň: Aleš Čeněk, 2011, s. 36.

40 Zákony č. 162/1920 Sb. z. a n., o Ústavním soudě, a č. 255/1922, Jednací řád Ústavního soudu.
} 
Dopisem z 11. června 1920 se obrátilo Předsednictvo ministerské rady na prezídium Civilní správy Podkarpatské Rusi s prosbou o předložení návrhu na jmenování člena a náhradníka do Ústavního soudu. ${ }^{41}$ Prezídium Civilní správy se pochopitelně obrátilo na podřízené úřady s požadavkem na předložení vlastních návrhů, ale jak prozrazuje hlášení Županského úřadu v Mukačevě z 9. srpna 1920, nebylo vhodných osob, přesto však bylo několik osob navrženo se zdůrazněním jejich osobnostních rysů (např. mírnosti) a loajality k republice. ${ }^{42}$ Ovšem i tak byl mukačevský župan úspěšnější, než jeho berehovský kolega, který nadřízený úřad informoval s odvoláním na „nejlepší vědomí a svědomí nemohu ze zdejšího obyvatelstva navrhnouti požadovaného terna. Veškeré osoby, jež by tu mohly přijíti v úvahu, jsou politicky naprosto nespolehlivými..." “43 Županský úruad ve Velkém Bočkově nepodal žádný návrh, nebot' mu pošta dorazila se zpožděním, ${ }^{44}$ ovšem o to kurioznější návrh to později byl: „viceguvernér Dr. Ehrenfeld, dr. Braščajko, Dr. Kudler, Dr. Bláha, Dr. Ojchajlo, Dr. Medved“..45 Skutečnost, že Ehrenfeld a Bláha byli zjevně Češi, kteří by nesymbolizovali skutečné propojení Podkarpatské Rusi s Československem, navrhovatele zřejmě netrápila - potřeboval jen splnit zadání v podobě odevzdání jmenného seznamu. Nejrozumnější návrh na terno podal užhorodský županský úřad - pravda, asi jako jediný měl z čeho vybírat - ale jen pro terno, vhodné kádry pro náhradníky již nebyly. Užhorodský župan tedy doporučil Ilju Hadžegu (předsedu užhorodské sedrie), Jana Zeltvaye (vládního komisaře města Užhorod) a Kornela Mogilnického (soudního radu při soudním referátu Civilní správy Podkarpatské Rusi). ${ }^{46}$ Za těchto okolností Předsednictvo ministerské rady dopisem 5. listopadu 1920 urgovalo vyřízení svého průvodního dopisu. ${ }^{47}$

Vláda v létě 1920 neoslovila jen Civilní správu Podkarpatské Rusi, ale vyzvala též všechny relevantní zákonodárné a soudní sbory, aby poslaly své návrhy. Za neexistující sněm tak činila právě Civilní správa, která připravovala podklady vládě. Viceguvernér Petr Ehrenfeld však nemohl dodat požadovaný počet tří kandidátů, nebot', jak napsal do Prahy, „těžko nalézti osoby, které by kladeným požadavkům úplně vyhovovaly“. Navrhl proto Kolomana Volenského a Nikolaje Mašiku jako členy, s tím že náhradníky měli být Jan Zeltvay a Viktor Adamkovich. Vláda proto sama doplnila shromážděné kandidátky o úřredníky rusínského původu Jana Bezecného a Ilju Hadžegu. Vnitřně se počítalo, že doplnění z řad státních úředníků by bylo pouze formální, nebot' v úvahu ke jmenování připadaly „,především osoby národnosti rusínské, navržené citovaným prrípisem civilní správy pro Podkarpatskou Rus“. Byla to právě vláda, která na místě neexistujícího sněmu Podkarpatské Rusi, měla jmenovat kandidáty - navrhovala výhradně osoby rusínského původu, ačkoliv to zákon výslovně nevyžadoval. Všeobecně totiž panoval koncensus, že správa Podkarpatské Rusi by měla vést k tomu, aby prim v jejím životě hrálo domácí slovanské obyvatelstvo. Vláda tedy v únoru 1921 navrhla do Ústavního soudu velkosevljušského advokáta Kolomana Volenského, mukačevského okresního soudce Viktora Adamkoviche

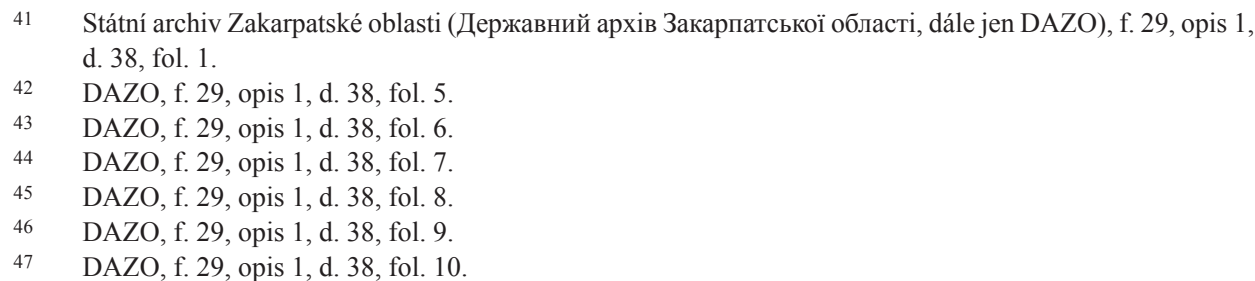


a užhorodského sedriálního soudce Ilju Hadžegu. Náhradníky byli navrženi berehovský prokurátor Nikolaj Mašika, vládní komisař města Užhorod Ivan Zeltvay a berehovský tabulární soudce Jana Bezecný. ${ }^{48}$

Koloman Volenský, jehož navrhla Předsednictvu ministerské rady Civilní správa Podkarpatské Rusi již ve svém dopise z 30. listopadu 1920, byl 21. ř́ina 1921 prezidentem republiky jmenován. Náhradníkem se stal Nikolaj Mašika. ${ }^{49}$

Ústavní soud se prvně sešel 17. listopadu 1921 v 13:00 a záhy se zjistilo, že Volenský se z neznámých důvodů nedostavil, tudíž se nemohl zúčastnit napřr. volby místopředsedy soudu, ale př́ítomný náhradník Mašika mohl alespoň pomoci se sčítáním hlasů. Na dalších pracovních jednáních se Mašika, plně vytížený v důsledku nedostatku soudního personálu na východě republiky, popř. ze zdravotních důvodů, již neúčastnil, ${ }^{50}$ zatímco Volenský pro svoji nepř́tomnost měl velmi dobrou omluvu - dne 7. prosince 1920 zemřel v Budapešti. Logicky se Předsednictvo ministerské rady ptalo, proč nebylo zavčas informováno o této informaci životního významu a nadto chtělo jmenovací dekret zpět. ${ }^{51}$ Rodina zesnulého však požádala, aby jmenovací dekret byl jí ponechán na památku. ${ }^{52}$ Syn zemřelého, rovněž Koloman, protokolárně uvedl:

„Jménem svým a své rodiny prosím, aby dekret na mého otce zemřelého, jakožto bývalého člena soudu ústavního znící byl rodině naší ponechán, ježto tvoří jednak památku po zemřelém otci, jednak i cennou vzpomínku rodinnou na to, jaké cti se kdysi př́slušníku jeho rodiny ze strany vlády československé ustanovením na místo tak čestné, dostalo. Z pohnutek těchto čistě ideálních prosím opětovně za ponechání dekretu v rukou rodiny. “53

Podkarpatoruské úřady s dalšími pokusy o získání dekretu vyčkávaly na další pokyny z Prahy. ${ }^{54}$ Předsednictvo ministerské rady souhlasilo s ponecháním dekretu rodině, ale Civilní správě vytklo neoznámení Volenského úmrtí - Civilní správa se bránila až drzým sdělením, že nebyla informována, že zesnulý byl jmenován ústavním soudcem. Po této nepřímé výtce je zřejmé, že se Předsednictvo ministerské rady rozhodlo vzít věci pevně do svých rukou, nebot' informovalo podřízený úřad, že ,aby byl zachován početní poměr mezi členy Ústavního soudu vzatých z řad státních úředníků a členy Ústavního soudu jmenovaných z jiných oborů právnických, budiž kandidát ten vzat z právníků - neúredníků - pokud možná ze stavu advokátského“ a podrážděně reagovalo i na předchozí obranu Civilní správy: „Konečně nutno podotknouti, že důvod, kterým omlouvá civilní správa neoznámení úmrtí dr. Volenského, nelze uznati za postačující, jelikož povinnost k ohlášení vznikla pro civilní správu ne teprve okamžikem doručení dekretu, nýbrž již okamžikem úmrtí dr. Volenského, nebot' tento fakt znamenal podstatnou změnu tamního návrhu na obsazení ústavního soudu. Nutno tudíž toto opomenutí civilní správě vytknouti. “ Nadřízený úřad má vždycky pravdu. Pro návod, kde hledat, zároveň padl dotaz na eventuální změny v úředním zařazení soudců Viktora Adamkoviche a Ilji Hadžegy, kteří byli již dříve

\footnotetext{
48 LANGÁŠEK, op. cit., s. 44-49, 108; NA, f. PMR, kart. 512, svazek Ústavní soud 1.

49 NA, f. PMR, kart. 512, svazek Ústavní soud 1.

50 NA, f. Ústavní soud (dále jen ÚS), kart. 1, sign. Pres 1, kart. 3, sign. Spr 4.

51 NA, f. PMR, kart. 512, svazek Ústavní soud 1; DAZO, f. 29, opis 1, d. 38, fol. 11.

52 DAZO, f. 29, opis 1, d. 38, fol. 13.

53 DAZO, f. 29 , opis 1, d. 38 , fol. 14

54 DAZO, f. 29 , opis 1, d. 38 , fol. $13 \mathrm{v}$.
} 
navrženi. ${ }^{55}$ Civilní správa dala podřízeným orgánům tři dny na dodání návrhů, ${ }^{56}$ ale župan ve Velkém Sevljuši rychle ohlásil, že „při nejlepší snaze není mi možno z celého obvodu“ opatřit „návrh positivní“ $57 \mathrm{~V}$ podobném duchu se nesla vyjádření některých dalších úřadů. ${ }^{58}$ Mukačevský župan však měl přeci jen širší možnost a hrdě ohlásil, že kontaktoval soudní úřady a navrhl advokáta Ivana Soliče, ženatého řeckého katolíka, hlásícího se k velkoruské orientaci, jenž pocházel ze selské rusínské rodiny a za ženu měl schovanku místního „,arcidiákona Kosseje“. Důležitá byla poznámka: „Politicky se nijak neexponuje.“59

S uvedenými návrhy, včetně návodu, kde hledat, a jistě nepř́ijemné výtky, je o to překvapivější postup Civilní správy Podkarpatské Rusi, která se přes výše uvedenou krátkou lhůtu podřízeným úřadům nechala ze strany Předsednictva ministerské rady opakovaně upomínat o zaslání př́islušného návrhu. ${ }^{60}$ Teprve poté se Předsednictvo ministerské rady dozvědělo, že ,,dle hlášení všech podřizených županských úřadů nelze nalézti mezi zdejšími advokáty vhodného kandidáta na místo člena Ústavního soudu“. Civilní správa zároveň zažádala o sdělení, zda může hledat mezi úředníky státními. O Adamkovichovi i Hadžegovi byly zároveň podány informace týkající se jejich stávajícího pracovního zařazení, ${ }^{61}$ ačkoliv si to pracovníci Předsednictva ministerské rady mohli snadno sami zjistit ze jmenovacích spisů obou mužů opatrovaných v Předsednictvu ministerské rady. Zřejmě se obávali opakování ostudy jako v př́padě Kolomana Volenského. Poněkud provokativní postup Civilní správy Podkarpatské Rusi byl patrně ovlivněn přípisem užhorodského župana, který jednoznačně sdělil, že ve svém obvodě může doporučit výhradě Ilju Hadžegu, jenž byl velmi dobře jazykově vybaven (ovládal češtinu, ruštinu, němčinu a mad'arštinu) a byl vysoce hodnocen po odborné a pracovní stránce: „Jest velmi schopným a nadaným právníkem a velmi svědomitým úředníkem. “62

Předsednictvo ministerské rady nakonec pochopilo, že kádrové zdroje jsou vskutku omezené a dopisem z 30. března 1922 sdělilo Civilní správě Podkarpatské Rusi, že nejlepší by bylo hledat mezi soudci, kteří jsou přeci jen nezávislejší než běžní správní úřredníci. Natvrdo také uvedlo, že chce výhradně kandidáty rusínské národnosti. ${ }^{63}$ Prezidentu republiky nakonec bylo předloženo nové terno: Konstantin Petrovič Mačik, Igor Fengya a Ilja Hadžega. Volenského pozici nakonec zaujal viceprezident košické soudní tabule Konstantin Petrovič Mačik. Náhradníkem byl znovu vybrán Nikolaj Mašika. ${ }^{64}$ Mačik se pak dle možnosti jednání fyzicky účastnil ${ }^{65}$ a na soud nastoupil 25 . května $1922,{ }^{66}$ přičemž ale slib složil až na schůzi soudu dne 23. záŕí 1922. ${ }^{67}$

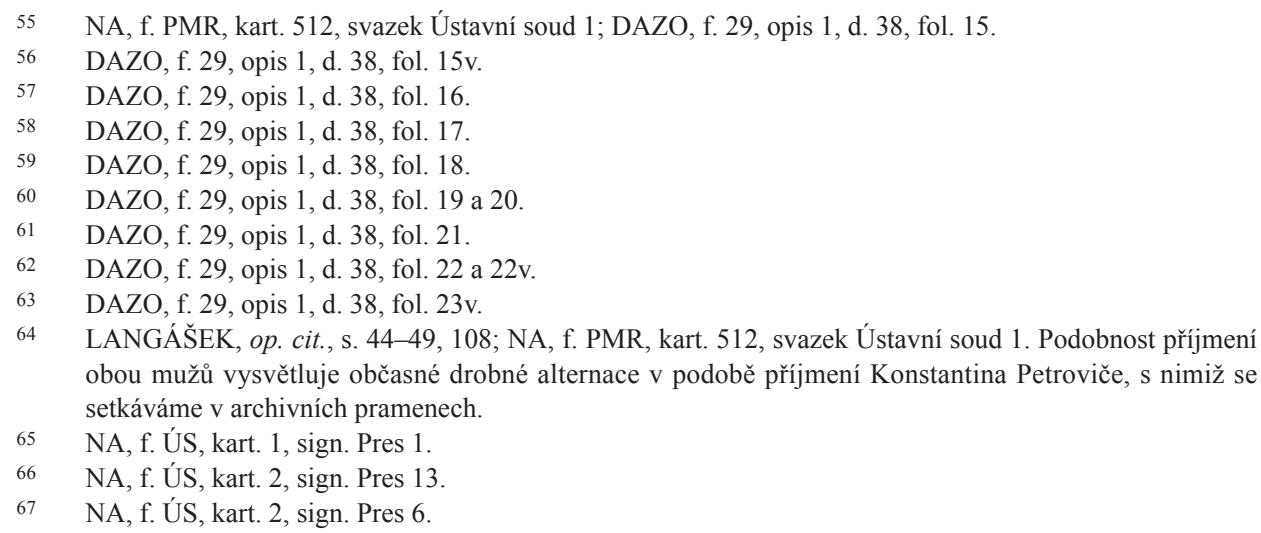


Ovšem i mezi rusínskými představiteli vládla poněkud menší informovanost, tudíž se v březnu 1926 guvernér Podkarpatské Rusi Anton Beskid domáhal jmenování podkarpatoruského člena Ústavního soudu a navrhl Josefa Kaminského, bývalého člena Národního shromáždění, Igora Petrika, veřejného notáře v Užhorodě, a Ivana Želtvaye, užhorodského župana. Předsednictvo ministerské rady guvernérovi jen sdělilo datum Mačikova jmenování. ${ }^{68}$ Tento chaos na rusínské straně je vysvětlitelný tím, že Rusíni z Podkarpatské Rusi a Slovenska se mezi sebou sžívali až během první republiky ${ }^{69}$ - do té doby byly jejich kontakty kupodivu omezené, ač byli součástí uherské části monarchie.

Již zmíněný viceprezident Soudní tabule v Košicích Konstantin Petrovič Mačik ještě krátce po první světové válce sloužil v jugoslávské Subotici, ale pozitivně reagoval na výzvu československého Ministerstva spravedlnosti a přešel do československých služeb. Při odchodu z Jugoslávie mu tamní vláda udělila řád Bílého orla. Jeho zisk pro československou justici v roce 1922 byl nepochybným př́nosem, nebot' pomohl zkonsolidovat neuspořádané poměry a na vlastní náklady vydal překlad civilního řádu a rusko-mad'arský terminologický právnický slovník. Při odchodu do penze počátkem třicátých let mu byl udělen zasloužený dík vlády, nebot' v úřadě ,,vynikl nestranností a zralostí úsudku, a zvláště se zasloužil o vybudování podkarpatoruského oddělení vrchního soudu v Košicích po stránce judikaturní“ “ ${ }^{70} \mathrm{~V}$ rámci Ústavního soudu mu coby zpravodaji byly přiděleny některé úkoly, např. opatření Stálého výboru ze dne 29. září 1920, jímž se mění a doplňují ustanovení rakouského zákona ze dne 22. ledna 1902, čís. 40 ř. z. a uher. zák. čl. XXVI z roku 1901, o poplatcích konsulárních (č. 564/1920 Sb. z. a n.). ${ }^{71}$ Mačik se pak této úlohy zhostil na jednání 27. dubna 1923 a jeho návrh byl všemi hlasy schválen. Ostatně Mačik se neveřejných schůzí účastnil velmi disciplinovaně. ${ }^{72}$

\section{Ústavní soud a zástupci Podkarpatské Rusi v druhém funkčním období}

Po vypršení desetiletého funkčního období přestal Ústavní soud působit, ačkoliv přijal usnesení, že bude v činnosti do jmenování nových členů, ${ }^{73}$ jejichž hledání také krátce na to začalo. V př́ípadě podkarpatoruských zástupců Ministerstvo vnitra navrhovalo v roce 1932 za členy Jana Zeltvaye, mukačevského veřejného notáře, Josefa Hofmana, prezidenta Krajského soudu v Berehovu, a Antonína Štefana, rachovského advokáta, přičemž náhradníky měli být Karel Loyka, vrchní rada politické správy v Užhorodě, Ilja Hadžega, prezident Krajského soudu v Užhorodě, a Igor Petrik, užhorodský veřejný notář. Ministerstvo spravedlnosti ovšem mělo poněkud jiný názor, kdy za členy soudu navrhovalo již zmíněného Jana Zeltvaye, dále Karla Rybu, radu politické správy v Užhorodě, a Ilju Hadžegu, přičemž náhradníky měli být Josef Hofman, Karel Loyka a Michal Braščajko, jenž působil jako užhorodský advokát. Ministerstvo vnitra s návrhy souhlasilo, ale doporučilo, aby jako první náhradník figuroval Karel Loyka. Než došlo ke jmenování nové sestavy soudu, tak Hofman v roce 1933 zemřel a o rok později jej následoval Zeltvay. Ústřední úřady proto v roce 1935 svoje podkarpatoruské návrhy upravily na Ilju Hadžegu, Karla Rybu

\footnotetext{
68 NA, f. PMR, kart. 512, svazek Ústavní soud 1.

69 ŠVORC, Namiesto úvodu: Slováci a Rusíni pred vznikom Československa, s. 21-22.

70 NA, f. PMR, kart. 1050, čj. 1575/1932.

$71 \quad$ NA, f. ÚS, kart. 1, sign. Pres 4.

72 NA, f. ÚS, kart. 2, sign. Pres 6.

73 NA, f. PMR, kart. 512, svazek Ústavní soud 1.
} 
a náhradníky Karla Loyku, Vladimíra Kutku, vrchního soudního radu u Vrchního soudu v Košicích, a Michala Braščajka. Jak je zřejmé, chyběl třetí kandidát do terna na řadového soudce, přičemž tím třetím se v roce 1936 stal Antonín Štefan, který se v pořadí kandidátů dostal na druhé místo před Rybu odsunutého na místo třetí. Jenže Štefan byl na jaře 1937 vyměněn za Michala Braščajka a jeho místo jako třetího náhradníka zaujal Alexandr Hassai, veřejný notář v Mukačevu.

Mezitím se objevila nutnost Ústavní soud reálně oživit, nebot' mu začaly přicházet př́ípady. Nakonec se jmenování 11. června 1937 dočkal Ilja Hadžega a náhradníkem se stal Karel Loyka. ${ }^{74}$ Oba se zúčastnili ustavující schůze 10. května 1938, ale aktivně na ní nevystoupili, byt' je jistě potěšilo, že mají nárok na největší diety ze všech členů v podobě čtyř dnů cesty - dva dny do Prahy a dva dny zpět. ${ }^{75}$ Nutno však přiznat, že i v druhé polovině třicátých let vládl (nejen) v oblasti soudní správy nedostatek rusínských kandidátů, nebot' údajně ze strany Rusínů nebyl zájem o práci v justiční správě, ${ }^{76}$ tudíž byl osvědčený Hadžega více než dobrou volbou.

Nepřekvapí proto, že když byli na slavnostní večeře u prezidenta republiky zváni zaměstnanci justice, kteří by reprezentovali Podkarpatskou Rus nejen jako lokalitu svého působení, ale i jako místo svého původu, byli mezi zvanými Konstantin Petrovič Mačik a Ilja Hadžega. ${ }^{77}$

\section{Ústavní soud o Podkarpatské Rusi}

Jelikož ústava a mezinárodní smlouvy zaručovaly Podkarpatské Rusi autonomii, která nebyla provedena ani během zavádění žup ${ }^{78}$ a ani během pozdější zemské úpravy ${ }^{79}$ správního aparátu republiky, je pochopitelné, že političtí představitelé Podkarpatské Rusi začali ve třicátých letech tuto otázku více zdůrazňovat, zvláště když o svá práva bojovaly i další národnosti a menšiny žijící na území státu. Oproti německé a slovenské reprezentaci však rusínská politická elita byla velmi roztř́ššěná a tím pádem i slabá, tudíž českoslovenští vrcholní představitelé věnovali pozornost jiným nespokojencům. Přesto došlo k mírné úpravě dosavadních norem týkajících se správy Podkarpatské Rusi v podobě zákona č. 172/1937 Sb. z. a n., o prozatímní úpravě právního postavení guvernéra Podkarpatské Rusi a o souvislých opatřeních organisačních. Tento zákon někteří místní politici označili za kamufláž, aby Praha nemusila dát Podkarpatské Rusi to, co jí náleželo. ${ }^{80}$ Tato norma tedy stěží plně uspokojila již dozrávající Rusíny, přičemž problematickým se stalo i samotné naplnění zákona, zejména jmenování guberniální rady, která se nikdy nesešla. ${ }^{81}$

\footnotetext{
74 LANGÁS̆EK, op. cit., s. 148-149, 228; NA, f. PMR, kart. 512, svazek Ústavní soud 2.

75 NA, f. ÚS, kart. 1, sign. Pres 1.

76 Slovenský národní archiv, f. Vrchní soud Košice (dále jen SNA, f. VS Košice), kart. 2, inv. č. 7, čj. 2/ dův1930.

77 SNA, f. VS Košice, kart. 1, inv. č. 3, čj. 4/dův1926.

78 K tomu viz HUBENÝ, D. Československý župní zákon a Podkarpatská Rus. In: Аркасівські читання. Матерілаи VII міжнародної науково-практичної конференції 26. квітня 2017 р. Міколаїв: МНУ імені В.О. Сухомлинського, 2017, с. 47-49.

79 K tomu viz HUBENÝ, D. Podkarpatská Rus a reorganizace československé správy zákonem č. 125/1927 Sb. z. a n. In: Питання нової та новітньої історії. Збірник наукових працъь. Випуск 6. Міколаїв: МНУ імені В.О. Сухомлинського, 2017, s. 14-22.

80 PETRÁS̆, op. cit., s. 253.

81 PEŠKA, Z. Nové zřizení Podkarpatské Rusi. Praha: Orbis, 1938, s. 44-46.
} 
Na zákon si u Ústavního soudu stěžoval poslanec Štefan Fencik z Národního sjednocení/Ruské nacionálně autonomní strany. Ve své stížnosti z 1. dubna 1938 dokládal, že zákon č. 172/1937 Sb. z. a n. je neplatný, nebot' odporuje ve svých jednotlivých částech ústavě, napřr. že gubernátor může zasahovat do jazykových otázek, ke kterým je však podle ústavy př́ślušný výhradně podkarpatoruský sněm. Dále zastával názor, že i zemský úřad, „k jehož pravomoci náleží i věci autonomní, musí býti autonomním, a nikoliv úřadem státním“. Logicky na závěr své stížnosti žádal, aby Ústavní soud prohlásil naříkaný zákon za neplatný. Ústavní soud ale předal dne 19. května 1938 Fencikovu stížnost k vyřízení Nejvyššímu správnímu soudu. ${ }^{82}$

V souvislosti s projednáváním vládního návrhu zákona o prozatímní úpravě postavení guvernéra Podkarpatské Rusi (pozdější zákon č. 172/1937 Sb. z. a n.) přijaly obě komory Národního shromáždění rezoluce vyzývající vládu ke zřízení samostatného Vrchního soudu v Užhorodě. Ministerstvo spravedlnosti se proto obrátilo na košický vrchní soud a tamní vrchní státní zastupitelství s dotazem, jak se k takovému návrhu staví - odpovědi však byly záporné s poukazy na malý počet soudců (kolem stovky) působících na Podkarpatské Rusi, z nichž by se jen stěží naplnila odvolací a revizní stolice. Tyto problémy byly ještě násobeny výbušnou jazykovou a národnostní problematikou, jak zmínil košický vrchní soud:

„Při nepatrném rozsahu území, pro které by vrchní soud v Užhorodě působil a ve kterém rozvířeny jsou nejen otázky národnostní a náboženské, nýbrž i jazykové (Velkorusové, Ukrajinci), doléhaly by spory politické i národnostní, i rozpory jazykové a působily by vztahy společenské a př́buzenské na soudce vyšlé z tohoto prostředí prrirozeně znatelněji, než na soudce vyšlé z jiného prostředí (ze Slovenska, Čech). V takovémto prostředí bylo by těžko odvrátiti nebezpečí, aby nevyskytly se bezdůvodné stížnosti a podezírání těchto soudců ze zaujatosti, i když podezření tato budou naprosto bezzákladná."83

K realizaci samostatného vrchního soudu skutečně došlo za druhé republiky, kdy se plně projevily všechny místní vzájemné nenávisti. Stalo se tak nařizením vlády č. 225/1938 Sb. z. a n., jímž se zřizuje pro území Podkarpatské Rusi vrchní soud a vrchní státní zastupitelství se sídlem v Užhorodě, které z dosavadního obvodu Vrchního soudu v Košicích vyloučilo obvody krajských soudů v Berehovu, Chustu a Užhorodě a zároveň zrušilo podkarpatoruské oddělení u Vrchního soudu v Košicích.

Nařízení vlády č. 225/1938 Sb. z. a n. bylo jako opatření Stálého výboru zasláno na přezkum Ústavnímu soudu. Původním zpravodajem tohoto opatření byl určen člen Ústavního soudu a prezident Krajského soudu v Užhorodě Ilja Hadžega, jenž však v důsledku vídeňské arbitráže zůstal na Mad'ary okupovaném území. ${ }^{84} \mathrm{Za}$ zmínku stojí, že navzdory trudné situaci po 2. listopadu 1938 a následné urychlené evakuaci odstupovaného území, se Hadžega plně omluvil z tohoto jednání. ${ }^{85}$ Omluvný Hadžegův dopis z 5. listopadu 1938 však stojí za pozornost:

\footnotetext{
82 NA, f. ÚS, kart. 8, sign. Úst 34. Ve fondu Nejvyšší správní soud (NSS) se mi však pokračování této causy nepodařilo dohledat, resp. nenalezl jsem žádný záznam o tom, že by ji NSS vůbec přijal. Se stejným výsledkem pátral LANGÁŠEK, op. cit., s. 36, pozn. č. 30.

83 SNA, f. VS Košice, k. 2, inv. č. 14, č. j. 10/dův1937.

84 NA, f. ÚS, kart. 8, sign. Úst. 41.

85 NA, f. ÚS, kart. 2, sign. Pres 6.
} 
„Slovutný pane předsedo Ústavního soudu!

Málo lidí učinilo na mne tak hluboký dojem, jak Vy slovutný pane.

Do budovy Ústavního soudu vstoupil jsem vždy se svatým vnuknutím.

Bohužel, Užhorod odpadl od Československé republiky, a proto na zasedání Ústavního soudu, které

bude 15. XI. se konat, nemohu se dostavit.

Prosím, moji hlubokou úctu předat i jiným pánům kolegům.

Hlubokou

Úctou oddaný

Dr. Ilja Hadžega“" 86

Je zjevné, že v Hadžegovi měla Podkarpatská Rus a s ní i Československá republika na Ústavním soudu naprosto loajálního zástupce. Jenže soud musel působit dále, tudíž byl obratem do nového hlavního města Podkarpatské Rusi (Karpatské Ukrajiny) Chustu kontaktován Loyka. ${ }^{87}$ Samotné opatření však bylo nově přiděleno senátnímu prezidentu Františku Zikánovi a bylo to rozumné rozhodnutí - na neveřejnou schůzi konanou dne 15. listopadu 1938 se Loyka pro dopravní důvody nemohl dostavit. Toto jednání dospělo k závěru, že věc je bezproblémová a může se projednat na veřejném zasedání, které se uskutečnilo 24. ledna 1939. Za vládu se veřejného jednání zúčastnil ministerský rada dr. Josef Křepinský z Ministerstva spravedlnosti, který předtím dlouho působil na Podkarpatské Rusi. Na tomto zasedaní již za účasti Karla Loyky bylo nařízení vlády shledáno jednomyslně jako ústavní. Žádný z prrítomných soudců ani zástupce vlády neměl potřebu se vyjádřit $\mathrm{k}$ tomuto opatření. ${ }^{88}$

Brzké rozbití státu však neukončilo činnost Ústavního soudu, a to dokonce ani jeho vyjadřování se k událostem na Podkarpatské Rusi. Na plenární schůzi Ústavního soudu z 16. května 1939 za účasti Karla Loyky se všichni př́ítomní shodli na tom, že: „Pokud jde o Podkarpatskou Rus, dlužno konstatovati, že v uvozovacím zákonu k ústavní listině nepřihlíží se k teritoriálnímu principu, podle něhož by Podkarpatská Rus byla zvláštním způsobem zastoupena $\mathrm{v}$ ústavním soudu. Tento princip zná teprve zákon o ústavním soudu, kde však navrhovací právo sněmu Podkarpatské Rusi bylo suspendováno až do té doby, dokud se tento sněm neustaví. Tento sněm také se nikdy neustavil, a proto princip teritoriální ve složení ústavního soudu nikdy nebyl uplatněn. Proto také ústavní soud není odrazem teritoriálního rozdělení bývalé Československé republiky, a proto se ho územní změny nastalé před 16. březnem t. r. dotknouti nemohly. "Přítomný ústavní soudce německé národnosti Teodor Nußbaum se k těmto vývodům připojil. ${ }^{89}$

Závěr Ústavního soudu je velmi pozoruhodný, nebot' předtím proběhly volby do sněmu Karpatské Ukrajiny a jeho 32 poslanců se sešlo v učebně chustského gymnázia, kde mimo jiné odhlasovali samostatnost toho území. Karel Loyka, jako zaměstnanec zemského úřadu, jenž se z Užhorodu evakuoval do Chustu a stal se základem autonomní vlády, byl o těchto událostech samozřejmě zcela informován a lze se oprávněně domnívat, že

\footnotetext{
$86 \quad$ NA, f. ÚS, kart. 2, sign. Pres 6.

$87 \quad$ NA, f. ÚS, kart. 2, sign. Pres 6.

$88 \quad$ NA, f. ÚS, kart. 8, sign. Úst. 41.

89 NA, f. ÚS, kart. 1, sign. Pres 1.
} 
kolegy na Ústavním soudu informoval o turbulentním vývoji Podkarpatské Rusi v krátkém čase druhé republiky. Nelze ani zapomínat na to, že členy Ústavního soudu byli soudci Nejvyššího správního soudu, jenž zase poskytoval odborníky př́iležitostnému Volebnímu soudu, který na volby do sněmu Karpatské Ukrajiny obdržel tři stížnosti poukazující na předvolební násilí a více než pravděpodobné falšování voleb ze strany ukrajinských nacionalistů. ${ }^{90}$

Ani tímto odvážným usnesením se existence Ústavního soudu a jeho podkarpatoruského zástupce neuzavřela, nebot' jeho členové, včetně Karla Loyky, byli povinováni složit slib podle dekretu státního prezidenta č. 83/1940 Sb. Loyka tak s dalšími kolegy učinil 23. května 1940, někteří to stihli až druhý den. ${ }^{91}$ Z Mad'ary ovládaného území se na jaře 1941 ozval dokonce Ilja Hadžega, který zcela pozemsky požádal o proplacení cestovného a dalších výdajů za účast na jednání Ústavního soudu 25. října 1938.92 Předsednictvo ministerské rady tuto žádost předalo Ústavnímu soudu k vyřízení, ${ }^{93}$ který se požadavku vzápětí ujal a kladně jej vyř́ídil. ${ }^{94}$

\section{Závěr}

Zařazení otázky autonomie Podkarpatské Rusi do základního zákona státu představovalo demonstraci úmyslu provést autonomii, resp. že Československo nebere své závazky na lehkou váhu. Pravdou ovšem je, že - zcela pragmaticky - ústava nehovořila o tom, kdy bude kýženého ideálního stavu, tj. autonomie, dosaženo. ${ }^{95}$ Řešení autonomie Podkarpatské Rusi v ústavě se líbilo také některým slovenským politikům, zejména ze Slovenské národní strany, kteří v ní viděli vhodný vzor pro autonomii Slovenska. ${ }^{96}$ Ústava byla kladně přijata též domácími a říšskými Němci, ${ }^{97}$ ale i jinde v zahraničí: , uspokojila spojence v prvé řadě tím, že akcentovala úlohu svrchovaného československého lidu coby tvůrce i správce své ,demokratické republiky““.98 Problematickým se však stalo její naplnění v podobě udělení autonomie. Na druhou stranu se stát postaral o to, aby byly zájmy Podkarpatské Rusi ošetřeny přítomností jejích zástupců v nejrůznějších ústředních orgánech a organizacích Ústavní soud nevyjímaje -, třebas to leckdy přinášelo až nečekané obtíže.

\footnotetext{
90 Podrobněji viz HUBENÝ, D. Podkarpatoruské volby do sněmu a přezkum u Volebního soudu v roce 1939. Historie - otázky-problémy, 2014, č. 1, s. 181-190.

$91 \quad$ NA, f. ÚS, kart. 1, sign. Pres 5.

92 Tehdy proběhlo neveřejné jednání Ústavního soudu k vlivu některých zákonů na řízení před Ústavním soudem. NA, f. ÚS, kart. 2, sign. Pres 6.

93 NA, f. PMR, kart. 512, svazek Ústavní soud 3.

94 NA, f. ÚS, kart. 3, sign. Spr 4.

95 MOSNÝ, op. cit., s. 79-80.

96 ROGUL'OVÁ, op. cit., s. 183-186.

97 Podrobněji viz HUBENÝ, D. - HASIL, J. Postoj říšských a československých Němců k československé ústavě z roku 1920. In: ČECHUROVÁ, J. - ŠLEHOFER, L. a kol. Ústava 1920. Vyvrcholeni konstituování československého státu. Praha: Leges, 2011, s. 121-132.

98 MALENOVSKÝ, J. Vznik a zánik Československa na pozadí zásady sebeurčení národů. Právník, 2018, roč. 157 , č. 10 , s. 792 .
} 